\title{
Histopathological and proteomic responses in male Chinese rare minnow (Gobiocypris rarus) indicate hepatotoxicity following benzotriazole exposure ${ }^{\text {tr }}$
}

\author{
Xuefang Liang ${ }^{\text {a, }}$, Jinmiao Zha ${ }^{\text {b, c }}$, Christopher J. Martyniuk ${ }^{\text {e }}$, Zijian Wang ${ }^{\text {b, d }}$, Ji Zhao ${ }^{\text {a }}$ \\ ${ }^{a}$ School of Ecology and Environment, Inner Mongolia University, Hohhot 010021, China \\ ${ }^{\mathrm{b}}$ Key Laboratory of Drinking Water Science and Technology, Research Center for Eco-Environmental Sciences, Chinese Academy of Sciences, Beijing 100085, \\ China \\ c Beijing Key Laboratory of Industrial Wastewater Treatment and Reuse, Research Center for Eco-Environmental Sciences, Chinese Academy of Sciences, \\ Beijing 100085, China \\ d State Key Laboratory of Environmental Aquatic Chemistry, Research Center for Eco-Environmental Sciences, Chinese Academy of Sciences, Beijing 100085, \\ China \\ e Department of Physiological Sciences and Center for Environmental and Human Toxicology, UF Genetics Institute, College of Veterinary Medicine, \\ University of Florida, Gainesville, FL 32611, USA
}

\section{A R T I C L E I N F O}

\section{Article history:}

Received 15 November 2016

Received in revised form 5 May 2017

Accepted 4 June 2017

Available online 30 June 2017

\section{Keywords:}

Liver proteome

Histological damage

Oxidative stress

Benzotriazole

Chinese rare minnow (Gobiocypris rarus)

\begin{abstract}
A B S T R A C T
Benzotriazole (BT) and its associated derivatives are used ubiquitously in industrial processes, and can be detected in indoor temperature coolants and in chemicals designed to inhibit corrosion. This chemical has been widely detected in aquatic environments and shows some degree of environmental persistence. Evidence has shown that BT exposure can negatively affect endocrine systems and can result in neurotoxicity in fish. However, no study has examined whether this chemical exhibits hepatotoxicity in fish, and if so, what are the underlying mechanism associated with the damage. To address this knowledge gap, we measured the liver proteome of adult male Chinese rare minnow (Gobiocypris rarus) exposed to either $0.05,0.5$, or $5 \mathrm{mg} / \mathrm{L}$ BT for 28 days. Overall, 17 proteins were induced and 9 were reduced in abundance following BT treatment (ratio $>1.5, \mathrm{p}<0.05$ ). Pathway analysis revealed that cellular processes affected by BT included xenobiotic clearance, oxidative stress response, apoptosis, and translation. Moreover, transcripts related to these toxic pathways were also significantly affected by BT. In addition, rare minnows exposed to BT showed signs of hypertrophy of hepatocytes, nuclei pyknosis, and higher levels of cellular vacuolization compared to the controls, thus these early proteomic responses in the liver may be related to pathology (i.e. adverse outcome pathway). Our data demonstrate that BT dysregulates molecular responses in the liver and tissue pathology indicative of damage. This study provides new insight into BT hepatotoxicity in Chinese rare minnow.
\end{abstract}

() 2017 Elsevier Ltd. All rights reserved.

\section{Introduction}

There has been a significant increase in the emergence of new chemicals of concern in the aquatic environment, as improved analytical methods are now able to detect chemical contamination with higher sensitivity (Herrero et al., 2013; Richardson, 2009). Many of these chemicals enter into aquatic ecosystems and can

\footnotetext{
This paper has been recommended for acceptance by Dr. Harmon Sarah Michele.

* Corresponding author. School of Ecology and Environment, Inner Mongolia University, 235 West College Road, Hohhot, Inner Mongolia, 010021, China.

E-mail address: liangxf@imu.edu.cn (X. Liang).
}

bioaccumulate in the aquatic food web (Liu et al., 2011; Wang et al., 2015). Benzotriazoles such as $1 \mathrm{H}$-benzotriazole (BT) are industrial chemicals that are used in high volumes ( 9000 tons/year worldwide) in both consumer products (e.g. additives to household dishwashing agents) and industrial compounds such as anticorrosive and de-icing agents (Giger et al., 2006). Their wide application and resistance to biodegradation contribute to the dispersive occurrence of these compounds in the aquatic environment (Herzog et al., 2014; Liu et al., 2012). In fact, these chemicals can reach relatively high levels in some water systems. For example, BT has been detected in surface waters at concentrations ranging from 0.038 to $7.98 \mu \mathrm{g} / \mathrm{L}$ (Kiss and Fries, 2009; Loos et al., 2009; Voutsa et al., 2006; Wolschke et al., 2011), and higher 
levels of BT have been reported in wastewater effluent, ranging from 10 to $100 \mu \mathrm{g} / \mathrm{L}$ (Voutsa et al., 2006; Weiss and Reemtsma, 2005). BT has also been detected in drinking water in the UK, at a concentration of approximately $30.9 \mathrm{ng} / \mathrm{L}$ (Janna et al., 2011). In addition to water contamination, BT has also been detected in indoor dust (Wang et al., 2013) and human urine (Asimakopoulos et al., 2013a, 2013b). Thus, these compounds appear to be relatively ubiquitous chemicals in aquatic environments and may pose potential risk to human health.

Despite the persistence of BT and widespread use, data on how it affects aquatic organisms and humans are limited. The acute toxicity of BT for fathead minnows (Pimephales promelas) is reported to be relatively low, with a $\mathrm{LC}_{50}$ value of $65 \mathrm{mg} / \mathrm{L}$ (Pillard et al., 2001). However, in contrast to acute dosing experiments, chronic exposure to $\mathrm{BT}$ at much lower levels $\left(\mathrm{EC}_{10}\right.$ values varied from 0.97 to $3.94 \mathrm{mg} / \mathrm{L}$ ) has been associated with the inhibition of both growth and reproduction in aquatic invertebrates (Seeland et al., 2012), indicating that there may be uncharacterized risks to aquatic organisms. BT may also be an endocrine disruptor, and studies show that BT elicits adverse responses in marine medaka (Oryzias melastigma) (He et al., 2012) and rare minnow (Gobiocypris rarus) (Liang et al., 2014b). These studies are suggestive of an estrogenic mode of action, while antiandrogenic modes of action have been observed from studies conducted in zebrafish embryos (Fent et al., 2014). These data spur additional questions as to the mode of action for these compounds, and further studies are warranted to document the full range of any potential adverse effects.

We previously demonstrated that BT alters the mRNA levels of genes involved in the hypothalamic-pituitary-gonadal (HPG) axis and that BT can exert estrogenic disruption in rare minnow, based on alterations in the plasma E2 levels (Liang et al., 2014b). In addition, our previous proteomic study in the brain of female rare minnow has shown that BT may be related to neurotoxicity by interfering with cellular processes including cellular respiration, Gprotein signal cascades, $\mathrm{Ca}^{2+}$-dependent signaling, cell cycle and apoptosis (Liang et al., 2016). However, hepatotoxicity and the mechanism underlying BT toxicity at the protein level have not been investigated, despite the fact that the liver is the major detoxification organ for chemicals.

The objectives of this study were to examine the proteomic response in the liver of rare minnows exposed to BT in doseresponse experiments to learn more about the mechanisms of action of BT in fish. The rare minnow (Gobiocypris rarus) inhabits the upstream waters of the Yangtze River in China. This small bodied fish is ideal for toxicity testing because it is relatively straight forward to maintain laboratory cultures, it has a short life cycle, and it can produce hundreds of eggs. Therefore, the rare minnow is considered a premier small fish model for the assessment of chemicals in the environment in China (Zha et al., 2008). Furthermore, omics-based approaches (i.e., genomics, proteomics, and metabolomics) to inform mechanism-based toxicology have been adapted in rare minnows to better characterize toxicity and molecular pathways perturbed by chemicals (Liang and Zha, 2016). In this study, the proteomic response in the liver of rare minnow, as well as hepatic histopathology were carried out to assess the hepatotoxic potential of BT. Pathway analysis was conducted to synthesize proteome data to provide additional insight into the molecular processes that may underlie hepatotoxicity.

\section{Materials and methods}

\subsection{Experimental design and sampling}

Exposure experiments followed that as previously outlined in Liang et al. (2014b, 2016). Adult male Chinese rare minnows ( 10 months old) used in this experiment were maintained at the State Key Laboratory of Environmental Aquatic Chemistry, which is housed at the Research Center for Eco-Environmental Sciences and Chinese Academy of Sciences. Fish were cultured in $10 \mathrm{~L}$ glass aquaria with flow-through dechlorinated tap water. Water parameters were as follows: $\mathrm{pH}=7.2-7.6$, water hardness $=44.0-61.0 \mathrm{mg} \mathrm{CaCO} / \mathrm{L}$, and temperature $=25 \pm 1{ }^{\circ} \mathrm{C}$. Fish were allowed to acclimate to laboratory conditions for 2 weeks prior to the experiment. Healthy males based on visual inspection were randomly divided into 12 groups of 20 fish and were exposed to one of three concentrations of BT $(0.05,0.5,5 \mathrm{mg} / \mathrm{L})$ or to a wateronly control as BT is readily soluble in water.

Benzotriazole (BT, CAS no. 95-14-7, purity >99\%) was purchased from J\&K Chemical Ltd. (USA). Stock solutions were first prepared by dissolving BT in distilled water. The stock solutions were kept in 4-L brown glass container and were diluted with aquarium water to obtain the final concentration for exposure. The stock solutions were slowly added to glass mixing vessels by means of a peristaltic pump at a rate of $60 \mathrm{~mL} / \mathrm{h}$. These solutions were then mixed with dechlorinated tap water and dispersed to the exposure tanks, at a continuous flow rate of $5 \mathrm{~L} / \mathrm{h}$. Stock solutions were renewed every second day and dosing rates were checked twice daily.

Each experimental condition included three replicates for a total of 12 tanks. During the exposure, the fish were subjected to a photoperiod of 16:8 h light: dark and were fed newly hatched brine shrimp (Artemia nauplii) twice daily. After 28-days of experimentation, all fish were anesthetized on ice. The fish were dissected, and livers were removed and separated into two equal parts. One half of the liver was used for protein extraction and 2D gel electrophoresis, and the second half of the liver was used for RNA isolation and real-time PCR analysis. All samples at the time of dissection were immediately frozen in liquid nitrogen and stored at $-80^{\circ} \mathrm{C}$ until analysis.

A second experiment, longer than the first experiment, was conducted for 42 days. This second experiment was used to determine if liver damage occurred following a longer-term exposure to BT. No significant pathology was observed in low doses $(0.05$ and $0.5 \mathrm{mg} / \mathrm{L}$ ) after $28 \mathrm{~d}$ of BT exposure in a preliminary experiment (data not shown), thus $42 \mathrm{~d}$ was used to assess pathology and to better describe an adverse outcome pathway for BT.

\subsection{Proteomic analysis}

\subsubsection{Protein extraction and CyDye labeling}

Protein extraction and CyDye labeling were performed according to Liang et al. (2014a). Briefly, $50 \mathrm{mg}$ of frozen hepatic tissue from control and BT-treated fish were homogenized and sonicated intermittently over $5 \mathrm{~min}$ in $0.6 \mathrm{~mL}$ of ice-cold lysis buffer I ( $7 \mathrm{M}$ urea, $2 \mathrm{M}$ thiourea, $4 \% \mathrm{w} / \mathrm{v}$ 3-[(3-cholamidopropyl)dimethylammonio]-1-propanesulfonate (CHAPS), $1 \% \mathrm{w} / \mathrm{v}$ dithiothreitol (DTT), $30 \mathrm{mM}$ Tris and a cocktail of protease inhibitors (Roche)). To remove remaining tissue fragments and insoluble material, the homogenates were centrifuged for $10 \mathrm{~min}$ at $18,000 \times \mathrm{g}, 4^{\circ} \mathrm{C}$. The supernatant was then collected and $100 \mu \mathrm{L}$ of each sample protein extract was purified using a 2-D clean-up kit (GE Healthcare). Protein pellets were then resuspended in $50 \mu \mathrm{L}$ lysis buffer II (lysis buffer I, 0.5\% $\mathrm{pH} 4-7$ IPG buffer). Protein concentration was determined using a 2-D Quant kit (GE Healthcare) according to the manufacturer's protocol. Purified protein samples were randomized and minimally labeled with Cy3 or Cy5 fluorescent dyes (50 $\mu \mathrm{g}$ protein/400 pmol dye) as per the manufacturer's instructions (GE Healthcare). Cy2 was used to label a common protein pool that contained equal amounts of proteins from the samples and this acted as an internal standard for 2D gel electrophoresis. Labeling was performed on ice for 30 min in the dark and quenched with 
$10 \mathrm{mM}$ lysine for $10 \mathrm{~min}$, on ice and in the dark.

\subsubsection{Two-dimensional fluorescence difference gel electrophoresis and image analysis}

The methods for the 2D-DIGE analysis proceeded as that outlined in Liang et al. (2014a). Briefly, Cy2-, Cy3-, Cy5-labeled samples were mixed together and dissolved in rehydration buffer ( $7 \mathrm{M}$ urea, $2 \mathrm{M}$ thiourea, 4\% CHAPS, 1\% w/v DTT, 0.5\% pH 4-7 IPG buffer, and a trace of bromophenol blue). Samples ( $\mathrm{n}=3$ biological replicates per group) were then loaded onto $18 \mathrm{~cm}$ immobilized $\mathrm{pH}$ gradient (IPG) strips ( $\mathrm{pH} \mathrm{4-7,} \mathrm{GE} \mathrm{Healthcare),} \mathrm{and} \mathrm{subjected} \mathrm{to} \mathrm{first} \mathrm{dimension}$ iso-electric focusing (IEF) overnight using Ettan IPGphor (GE Healthcare, USA). After IEF, each strip was equilibrated twice for 15 min with constant mixing (60 rpm). This was achieved by first using $1 \%$ DTT followed by $2.5 \%$ iodoacetamide (IAA) in order to reduce and alkylate the proteins. The SDS-PAGE was performed using an electrophoresis system (Ettan Dalt six, GE Healthcare) and $10 \%$ polyacrylamide gel. Following electrophoresis, the gels were scanned with Typhoon Trio variable mode imager (GE Healthcare, $\mathrm{NJ}$ ) in each of the three channels that corresponded to the correct dye (488 $\mathrm{nm}$ for Cy2, $532 \mathrm{~nm}$ for Cy3, and $633 \mathrm{~nm}$ for Cy5). The intensity was adjusted to ensure that the maximum volume of each image was within 60-90 thousand. Image Master 2D Platinum 7.0 (GE Healthcare) software was used to analyze the images. A oneway ANOVA was used to determine if there were differences in abundance among spots. Protein spots were considered differentially expressed at a ratio $\geq 1.5(\mathrm{p}<0.05)$ and were pursued for identification.

\subsubsection{Protein identification}

Protein identification was conducted in accordance with the method previously published (Liang et al., 2016). Following the image acquisition, gels were stained with silver nitrate and protein spots were manually excised, decolorized, dehydrated and whitened according to Liang et al. (2016). The digested peptides were resuspended with $0.8 \mu \mathrm{l}$ of matrix solution (50\% acetonitrile, $0.1 \%$ trifluoroacetic acid, and semi-saturated a-cyano-4hydroxycinnamic acid). All mass spectra were acquired using a 4800 Plus MALDI-TOF/TOFTM Analyzer (Applied Bio-systems, USA) in positive reflectron mode. Signal-to-noise ratios of $\geq 50$ were required for tandem MS/MS analysis. The mass signals generated from the MS mode and the MS/MS mode were combined for protein identification. Mascot was set up to search an NCBI nonredundant (nr) database (zebrafish, 76,533 sequences, released Aug. 13, 2013; ray-finned fishes, 229,984 sequences, released Dec. 12,2012 ) assuming the digestion enzyme trypsin. Mono-isotopic masses were used at a peptide mass tolerance of $100 \mathrm{ppm}$. Cysteine carbamidomethylation was considered as a fixed modification, and the oxidation of methionine was specified as a variable modifications. Peptide and protein identifications were accepted if Confidence Interval \% (C.I. \%) values were greater than 95\%. The identified proteins were then matched to specific processes or functions by searching UniProt (http://www.uniprot.org/) and KEGG (http://www.genome.jp/kegg/) database.

\subsubsection{Pathway analysis}

For each differentially expressed protein, the official gene symbol was manually retrieved using gene card (http://www. genecards.org). The official gene symbols were then used to map proteins into the Pathway Studio 9.0 (Elsevier Life Science Solutions) and ResNet 10.0 for pathway analysis. This program uses expression, binding, and regulatory data among proteins to construct interaction networks. Pathways were built using direct connections with one neighbor. Using the "Name + Alias" function, thirty proteins mapped to the program. One protein did not successfully map as no mammalian homolog could be identified, while a second protein was excluded, as it is fish specific. In order to simplify the pathways, differentially expressed proteins across all three doses were considered as a whole for building pathways. As such, the median fold change of the protein was used to color pathways, and only proteins that were significantly altered in a BT treatment were used to calculate the median protein fold change. In the case of multiple spots (e.g. phosphorylase), the median value across all spots was used for the protein fold change relative to the control group. Sub-network enrichment analysis (SNEA) was also performed in the program to identify processes that were represented by the proteins. Criteria for an enriched cell process were that the network had to be significant (considered $P<0.05$ ) and there had to be more than 10 members in the network to represent the processes most likely altered by BT exposure at the proteome level. Further details on the program can be found in Langlois and Martyniuk (2013).

\subsection{Relative quantification by real-time PCR}

Total RNA was extracted from minnow liver $(n=6$ biological replicates per group) using Trizol reagent (Life Technology), and this was followed by DNase (Promega, USA) treatment. RNA integrity was measured using a $1.2 \%$ agarose gel $(0.5 \times$ TBE buffer, $150 \mathrm{v}, 15 \mathrm{~min}$ ) and RNA was of sufficient quality (i.e. no significant degradation based upon visual inspection of each sample). The concentration and purity of the samples were determined using a Multiskan ${ }^{\mathrm{TM}} \mathrm{GO}$ microplate spectrophotometer (Thermo Scientific, USA). For real-time PCR experiments, samples were adjusted to a $20 \mu \mathrm{L}$ volume with $2 \times$ GoTaq $^{\circledR}$ qPCR Master Mix (Promega, USA), $1 \mu \mathrm{L}$ of $10 \mu \mathrm{M}$ gene-specific primer, and $100 \mathrm{ng}$ first-strand cDNA synthesized from DNase-treated RNA. The relative abundance of $\beta$ actin was used to normalize the expression of target genes. All primer pairs used for real-time PCR are listed in Supplemental Table S1.

Real-time PCR reactions were assayed using the 7500 Real-Time PCR system (Applied Biosystems, USA). Each sample was analyzed in triplicate. The real-time PCR cycling parameters were as follows: initial denaturation step of $95^{\circ} \mathrm{C}$ for $10 \mathrm{~min}, 40$ cycles of $95^{\circ} \mathrm{C}$ for $30 \mathrm{~s}, 57^{\circ} \mathrm{C}$ for $40 \mathrm{~s}$, and $72{ }^{\circ} \mathrm{C}$ for $30 \mathrm{~s}$. To ensure amplicon specificity, a melt curve was generated at the last cycle of $95{ }^{\circ} \mathrm{C}$ for $30 \mathrm{~s}$, $57{ }^{\circ} \mathrm{C}$ for $30 \mathrm{~s}$, and $72{ }^{\circ} \mathrm{C}$ for $60 \mathrm{~s}$. Data were analyzed according to the $2^{-\Delta \Delta C t}$ method. Statistical analysis of variance was performed in SPSS (v18, USA). The normality of data was assessed using the Kolmogorov-Smirnov test and logarithmic transformation was performed prior to ANOVA to ensure data conformed to assumptions. The Levene's test of homogeneity of variance was used to test for adherence to ANOVA assumptions. A Dunnett's post-hoc test was used to compare each treatment with the control. All quantitative data are expressed as mean \pm S.E. A probability of $p<0.05$ was considered statistically significant.

\subsection{Histopathology}

Histopathology analysis followed that outlined in Liang et al. (2014b) and Chen et al. (2016). A total of 12 groups of 10 fish for each group $(0,0.05,0.5,5 \mathrm{mg} / \mathrm{L} \mathrm{BT})$ were used for histopathology analysis. Following necropsy of all male fish in the experiment, livers were excised and fixed in $4 \%$ paraformaldehyde for $24 \mathrm{~h}$. Liver samples were transferred to $70 \%$ ethanol, embedded in paraffin wax, and sectioned at 3-4 $\mu \mathrm{m}$ thick. Tissue sections were stained with hematoxylin and eosin ( $\mathrm{H}$ and $\mathrm{E}$ ) according to standard histological methods. Slides were visualized with an optical microscope BX53 (Olympus, Tokyo, Japan). Sections were imaged and analyzed using cellSens Standard software (Olympus, Tokyo, Japan). 
To determine if the liver was compromised at the tissue level, nucleated cells and akaryotes were counted. Five fields of visions were selected at random and analyzed ( $\mathrm{n}=6$ biological replicates per group were randomly selected from the original $10 \mathrm{fish}$ ). Statistical significance was considered to be $\mathrm{P}<0.05$ following a Student's t-test.

\section{Results}

\subsection{Proteome profiles of male rare minnow liver}

In order to identify sets of proteins that respond to BT exposure in male rare minnow, we compared the liver proteome of control and treated animals using 2D-DIGE (Fig. 1). A total of 46 protein spots were found to be significantly altered in abundance $(\geq 1.5$ fold) in one or more BT-treated groups compared to that of controls and 32 proteins were successfully identified (Table 1). Based upon the p-value and ratio criteria, there were 17 up-regulated proteins and 9 down-regulated proteins following BT treatments (Table 1). Most of these proteins were changed remarkably in the lowest concentrations of BT. Only four proteins were significantly increased (phosphoglucomutase 1) or decreased (heat shock 60kD protein 1, glucose-6-phosphate dehydrogenase, and homogentisate 1,2-dioxygenase) in higher concentrations $(0.5 \mathrm{mg} / \mathrm{L}$ and $5 \mathrm{mg} / \mathrm{L}$ groups), and these proteins did not show significant changes in abundance in the $0.05 \mathrm{mg} / \mathrm{L}$ group (Table 1 ).
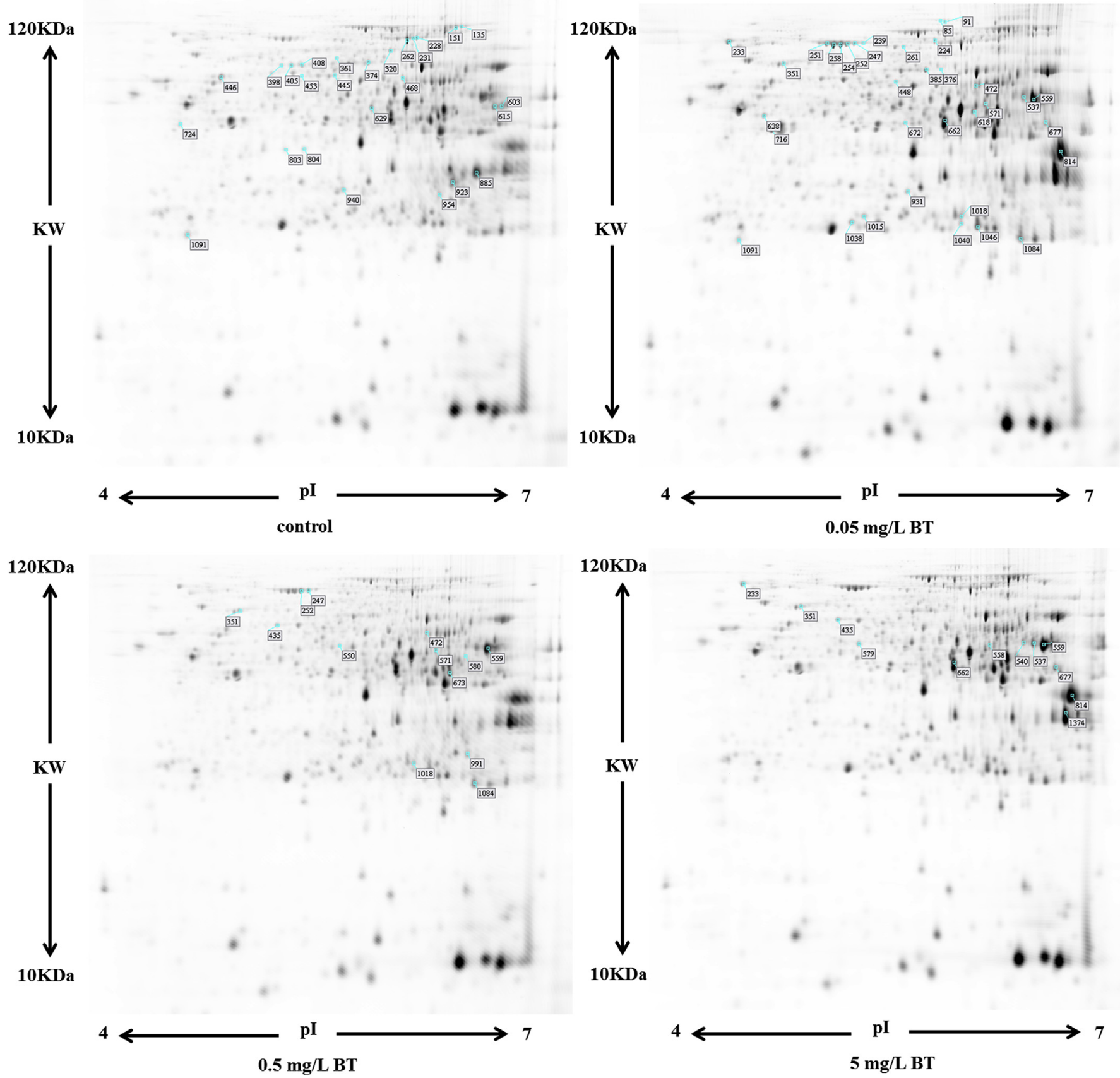

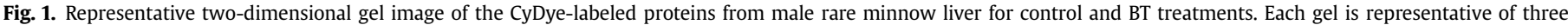

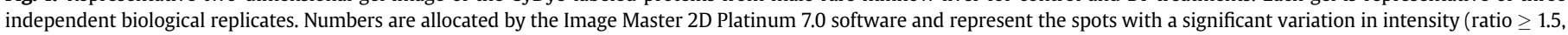
$\mathrm{p}<0.05$ ). The information for the proteins corresponding to the spot numbers is presented in Table 1. 
Table 1

A detailed list of protein spots identified by MALDI-TOF/TOF MS from the liver of male rare minnow following BT exposure.

\begin{tabular}{|c|c|c|c|c|c|c|c|c|c|}
\hline \multirow[t]{2}{*}{ Spot ID } & \multirow[t]{2}{*}{$\begin{array}{l}\text { GI accession } \\
\text { no. }\end{array}$} & \multirow[t]{2}{*}{ Protein name $\mathrm{a}^{\mathrm{a}}$} & \multirow[t]{2}{*}{ MW/PI } & \multirow[t]{2}{*}{$\begin{array}{l}\text { Matched } \\
\text { peptides }\end{array}$} & \multirow[t]{2}{*}{ score } & \multicolumn{3}{|c|}{$\begin{array}{l}\text { Fold change }{ }^{b} \\
\text { (treated vs control) }\end{array}$} & \multirow[t]{2}{*}{ Function category $^{c}$} \\
\hline & & & & & & $\begin{array}{l}0.05 \\
\mathrm{mg} / \mathrm{L}\end{array}$ & $\begin{array}{l}0.5 \\
\mathrm{mg} / \mathrm{L}\end{array}$ & $\begin{array}{l}5 \\
\mathrm{mg} / \mathrm{L}\end{array}$ & \\
\hline \multicolumn{10}{|c|}{ Protein identified in multiple spots } \\
\hline 247 & 56078768 & Phosphorylase & $111.8 / 5.50$ & 23 & 625 & 3.05 & 3.86 & 4.04 & $\begin{array}{l}\text { carbohydrate metabolic } \\
\text { process/glycogen } \\
\text { phosphorylase activity }\end{array}$ \\
\hline 251 & 56078768 & Phosphorylase & $111.8 / 5.50$ & 19 & 425 & 1.53 & 1.37 & 1.43 & \\
\hline 252 & 56078768 & Phosphorylase & $111.8 / 5.50$ & 19 & 279 & 2.22 & 2.41 & 2.34 & \\
\hline 254 & 56078768 & Phosphorylase & $111.8 / 5.50$ & 18 & 535 & 2.89 & 1.92 & 2.62 & \\
\hline 258 & 56078768 & Phosphorylase & $111.8 / 5.50$ & 22 & 549 & 2.30 & 1.46 & 1.91 & \\
\hline 398 & 56078768 & Phosphorylase & $111.8 / 5.50$ & 18 & 369 & -1.93 & -2.09 & -2.06 & \\
\hline 405 & 56078768 & Phosphorylase & $111.8 / 5.50$ & 17 & 445 & -1.70 & -2.69 & -3.41 & \\
\hline 408 & 56078768 & Phosphorylase & $111.8 / 5.50$ & 15 & 344 & -1.39 & -2.12 & -2.09 & \\
\hline 320 & 71373043 & iron regulatory protein 1 & $99.4 / 6.45$ & 10 & 295 & -2.33 & -2.73 & -3.29 & $\begin{array}{l}\text { metabolic process } / 4 \text { iron, } 4 \\
\text { sulfur cluster binding }\end{array}$ \\
\hline 361 & 71373043 & iron regulatory protein 1 & $99.4 / 6.45$ & 13 & 307 & -2.08 & -1.52 & -2.88 & \\
\hline 537 & 39645909 & Glutamate dehydrogenase & $60.3 / 8.45$ & 17 & 451 & 1.65 & 1.32 & 1.76 & $\begin{array}{l}\text { cellular amino acid } \\
\text { metabolic process/ } \\
\text { oxidoreductase activity }\end{array}$ \\
\hline 559 & 39645909 & Glutamate dehydrogenase & $60.3 / 8.45$ & 17 & 572 & 1.78 & 1.6 & 2.09 & \\
\hline 603 & 39645909 & Glutamate dehydrogenase & $60.3 / 8.45$ & 18 & 721 & -2.26 & -3.07 & -6.88 & \\
\hline 615 & 39645909 & Glutamate dehydrogenase & $60.3 / 8.45$ & 10 & 395 & -2.33 & -2.58 & -3.27 & \\
\hline 571 & 28278852 & $\begin{array}{l}\text { Methionine adenosyltransferase I, } \\
\text { alpha }\end{array}$ & $43.7 / 6.32$ & 8 & 182 & 2.37 & 2.24 & 1.7 & $\begin{array}{l}\text { S-adenosylmethionine } \\
\text { biosynthetic process; one- } \\
\text { carbon metabolic process }\end{array}$ \\
\hline 803 & 28278852 & $\begin{array}{l}\text { Methionine adenosyltransferase I, } \\
\text { alpha }\end{array}$ & $43.7 / 6.32$ & 11 & 227 & -2.38 & -3.19 & -3.22 & \\
\hline 814 & 82213364 & Fructose-bisphosphate aldolase B & $39.7 / 8.48$ & 4 & 98 & 1.61 & 1.57 & 2.06 & $\begin{array}{l}\text { Glycolysis/fructose- } \\
\text { bisphosphate aldolase } \\
\text { activity }\end{array}$ \\
\hline 885 & 82213364 & Fructose-bisphosphate aldolase B & $39.7 / 8.48$ & 6 & 132 & -2.52 & -2.79 & -4.47 & \\
\hline 923 & 123918122 & $\begin{array}{l}\text { glyceraldehyde-3-phosphate } \\
\text { dehydrogenase }\end{array}$ & $36.0 / 8.20$ & 9 & 458 & -2.31 & -5.77 & -7.73 & $\begin{array}{l}\text { Glycolysis/NAD binding; } \\
\text { NADP binding }\end{array}$ \\
\hline 1374 & 123918122 & $\begin{array}{l}\text { glyceraldehyde-3-phosphate } \\
\text { dehydrogenase }\end{array}$ & $36.0 / 8.20$ & 6 & 373 & 1.39 & 1.41 & 1.63 & \\
\hline \multicolumn{10}{|c|}{ Up-regulated proteins } \\
\hline 233 & 39645915 & $\begin{array}{l}\text { Heat shock protein } 90 \text {, } \\
\text { beta (Grp94), member } 1\end{array}$ & $91.4 / 4.77$ & 19 & 361 & 1.6 & 1.15 & 1.61 & $\begin{array}{l}\text { response to stress/ATP } \\
\text { binding }\end{array}$ \\
\hline 261 & 161612168 & Dmgdh protein & $97.9 / 6.54$ & 12 & 218 & 2.07 & -0.95 & 0.93 & glycine catabolic process \\
\hline 351 & 159155706 & Heat shock protein 8 & $71.4 / 5.32$ & 23 & 824 & 1.95 & 1.93 & 2.01 & $\begin{array}{l}\text { response to stress/ATP } \\
\text { binding }\end{array}$ \\
\hline 435 & 32766553 & Phosphoglucomutase 1 & $61.4 / 5.74$ & 11 & 498 & 1.4 & 1.51 & 2.22 & $\begin{array}{l}\text { galactose catabolic process; } \\
\text { glycogen biosynthetic } \\
\text { process }\end{array}$ \\
\hline 448 & 41393103 & $\begin{array}{l}\text { aldehyde dehydrogenase } \\
\text { family } 9 \text { member A1-A }\end{array}$ & $56.1 / 6.18$ & 9 & 95 & 1.6 & -1.01 & -1.01 & $\begin{array}{l}\text { aldehyde dehydrogenase } \\
\text { (NAD) activity }\end{array}$ \\
\hline 472 & 9622234 & catalase & $59.8 / 8.12$ & 13 & 382 & 1.88 & 1.67 & 1.49 & $\begin{array}{l}\text { hydrogen peroxide } \\
\text { catabolic process/catalase } \\
\text { activity }\end{array}$ \\
\hline 550 & 20339358 & Aldehyde dehydrogenase 2 & $57.2 / 6.05$ & 8 & 83 & 2.29 & 2.22 & 2.23 & $\begin{array}{l}\text { cellular aldehyde metabolic } \\
\text { process }\end{array}$ \\
\hline 618 & 302191716 & $\begin{array}{l}\text { 4-aminobutyrate aminotransferase, } \\
\text { mitochondrial }\end{array}$ & $56.3 / 7.61$ & 9 & 130 & 1.52 & 1.29 & 1.4 & $\begin{array}{l}\text { gamma-aminobutyric acid } \\
\text { metabolic process }\end{array}$ \\
\hline 662 & 28278417 & S-adenosylhomocysteine hydrolase & $48.5 / 6.33$ & 11 & 563 & 1.54 & 1.48 & 1.56 & $\begin{array}{l}\text { S-adenosylmethionine } \\
\text { cycle; one-carbon } \\
\text { metabolic process }\end{array}$ \\
\hline 672 & 357394863 & Probable imidazolonepropionase & $47.3 / 6.05$ & 7 & 231 & 1.94 & 1.6 & 1.05 & histidine catabolic process \\
\hline 677 & 82202412 & $\begin{array}{l}\text { Hydroxysteroid dehydrogenase-like } \\
\text { protein } 2\end{array}$ & $44.7 / 7.08$ & 9 & 141 & 1.59 & 1.49 & 2.19 & $\begin{array}{l}\text { oxidoreductase activity; } \\
\text { sterol binding }\end{array}$ \\
\hline 931 & 45709875 & Zgc:85683 & $32.5 / 5.38$ & 4 & 123 & 2.04 & 1.57 & 1.58 & catalytic activity \\
\hline 1015 & 528514207 & Uncharacterized protein & $29.3 / 5.2$ & 4 & 130 & 2.36 & 2.18 & 1.24 & $\begin{array}{l}\text { oxidation-reduction } \\
\text { process/oxidoreductase } \\
\text { activity }\end{array}$ \\
\hline 1018 & 44890340 & Phosphoglycerate mutase $1 \mathrm{a}$ & $29.1 / 6.19$ & 8 & 86 & 2.87 & 2.58 & 1.76 & $\begin{array}{l}\text { Glycolysis/ } \\
\text { phosphoglycerate mutase } \\
\text { activity }\end{array}$ \\
\hline 1040 & 528500056 & $\begin{array}{l}\text { Hypoxanthine } \\
\text { phosphoribosyltransferase } 1\end{array}$ & $24.9 / 6.21$ & 11 & 363 & 1.54 & 1.52 & 1.5 & $\begin{array}{l}\text { hypoxanthine metabolic } \\
\text { process; purine } \\
\text { ribonucleoside salvage }\end{array}$ \\
\hline 1046 & 514483217 & $\begin{array}{l}\text { Glutathione S-transferase theta } \\
\text { 1a [Carassius auratus] }\end{array}$ & $26.4 / 6.09$ & 5 & 186 & 1.52 & 1.47 & 1.28 & transferase activity \\
\hline
\end{tabular}


Table 1 (continued)

\begin{tabular}{|c|c|c|c|c|c|c|c|c|c|}
\hline \multirow[t]{2}{*}{ Spot ID } & \multirow[t]{2}{*}{$\begin{array}{l}\text { GI accession } \\
\text { no. }\end{array}$} & \multirow[t]{2}{*}{ Protein name $^{\mathrm{a}}$} & \multirow[t]{2}{*}{ MW/PI } & \multirow[t]{2}{*}{$\begin{array}{l}\text { Matched } \\
\text { peptides }\end{array}$} & \multirow[t]{2}{*}{ score } & \multicolumn{3}{|c|}{$\begin{array}{l}\text { Fold change }{ }^{\mathrm{b}} \\
\text { (treated vs control) }\end{array}$} & \multirow[t]{2}{*}{ Function category $^{\mathrm{c}}$} \\
\hline & & & & & & $\begin{array}{l}0.05 \\
\mathrm{mg} / \mathrm{L}\end{array}$ & $\begin{array}{l}0.5 \\
\mathrm{mg} / \mathrm{L}\end{array}$ & $\begin{array}{l}5 \\
\mathrm{mg} / \mathrm{L}\end{array}$ & \\
\hline 1084 & 8575790 & $\begin{array}{l}\text { Glutathione S-transferase } \\
\text { [Pimephales promelas] }\end{array}$ & $22.0 / 7.64$ & 4 & 127 & 2.54 & 2.17 & 1.5 & transferase activity \\
\hline \multicolumn{10}{|c|}{ Down-regulated proteins } \\
\hline 445 & 528496446 & $\begin{array}{l}\text { PREDICTED: fatty acid } \\
\text { synthase isoform X2 }\end{array}$ & $276.8 / 6.01$ & 17 & 255 & -2.83 & -5.7 & -4.38 & ND \\
\hline 446 & 528489998 & $\begin{array}{l}\text { Heat shock } 60 \mathrm{kD} \text { protein } \\
1 \text { (Chaperonin) }\end{array}$ & $61.4 / 5.56$ & 15 & 884 & -1.24 & -1.52 & -1.03 & $\begin{array}{l}\text { response to stress/ATP } \\
\text { binding }\end{array}$ \\
\hline 468 & 298201226 & $\begin{array}{l}\text { glucose-6-phosphate } \\
\text { dehydrogenase, } \\
\text { partial [Gobiocypris rarus] }\end{array}$ & $35.6 / 5.87$ & 11 & 250 & -1.43 & -1.87 & -1.29 & $\begin{array}{l}\text { pentose-phosphate shunt/ } \\
\text { NADP binding; glucose-6- } \\
\text { phosphate dehydrogenase } \\
\text { activity }\end{array}$ \\
\hline 629 & 10441585 & Homogentisate 1,2-dioxygenase & $45.2 / 6.37$ & 10 & 241 & -1.06 & -1.3 & -2.14 & $\begin{array}{l}\text { L-phenylalanine catabolic } \\
\text { process; tyrosine metabolic } \\
\text { process }\end{array}$ \\
\hline 724 & 41054972 & 40 S ribosomal protein $\mathrm{SA}$ & $34.2 / 4.75$ & 4 & 312 & -2.05 & -2.71 & -5.63 & $\begin{array}{l}\text { cell adhesion; ribosomal } \\
\text { small subunit assembly; } \\
\text { translation/laminin } \\
\text { receptor activity; structural } \\
\text { constituent of ribosome }\end{array}$ \\
\hline 940 & 182889192 & Zgc:153353 & $40.1 / 7.51$ & 7 & 130 & -1.62 & -1.61 & -1.16 & $\begin{array}{l}\text { hydrolase activity; metal } \\
\text { ion binding }\end{array}$ \\
\hline 954 & 182890800 & Zgc:101897 protein & $27.9 / 8.13$ & 6 & 75 & -2.18 & -1.49 & -0.81 & $\begin{array}{l}\text { glutathione transferase } \\
\text { activity }\end{array}$ \\
\hline 987 & 49900472 & $\begin{array}{l}\text { Sulfotransferase family } 1 \text {, } \\
\text { cytosolic sulfotransferase } 6\end{array}$ & $35.8 / 6.19$ & 7 & 125 & -1.81 & -1.86 & -2.18 & $\begin{array}{l}\text { estrone sulfotransferase } \\
\text { activity }\end{array}$ \\
\hline 1091 & 53733942 & Apolipoprotein A-I & $19.7 / 5.31$ & 3 & 77 & -1.94 & -1.52 & -1.88 & $\begin{array}{l}\text { cholesterol metabolic } \\
\text { process; lipid transport; } \\
\text { lipoprotein metabolic } \\
\text { process }\end{array}$ \\
\hline
\end{tabular}

\footnotetext{
a All proteins from Danio rerio database except specially noted by "[ ]" in the end of the protein name.

b The average fold changes as compared to the controls. The fold changes higher than or equal to 1.5 -fold are significant fold change values and are indicated by bold character. The down-regulations are noted by "-".

c Biological processes or molecular functions in GO terms. "ND" indicates that no function is defined for the protein.
}

In addition, among the protein spots identified, 6 proteins were detected in more than one spot (Table 1 ). For example, Protein spots 247, 251, 252, 254 and 258 were all identified as phosphorylase (PYGL), which appeared as a string of abundant spots on the gels (Supplemental Fig. S1). A shift in mass was also observed as protein spots 398, 405, and 408 were also identified as PYGL (Supplemental Fig. S1). Although each spot was significantly altered in abundance relative to control males, their expression patterns were not consistent (i.e. some modified or charged PYGL was increased in abundance while other modifications for PYGL were decreased). According to the median value across all spots and our criteria ( $\geq 1.5$-fold), the total abundance of PYGL was not significantly altered in the BT-treated groups compared to the control group (Table 1, Supplemental Fig. S1).

\subsection{Differentially expressed proteins and pathway analysis}

Thirteen proteins had a direct relationship among each other and these included heat shock $70 \mathrm{kDa}$ protein 8 (HSPA8), heat shock protein $90 \mathrm{kDa}$ beta (Grp94), member 1 (HSP90B1), and catalase (CAT) (Supplemental Fig. S2). These proteins increased in abundance following BT treatment and are involved in the oxidative stress response. Thus, these proteins comprise a sub-network that is regulated by BT. Proteins regulated by BT were also associated with xenobiotic clearance. Specific proteins related to xenobiotic clearance included glutamate dehydrogenase 1 (GLUD1), aldehyde dehydrogenase 9 family, member A1 (ALDH9A1), 4-aminobutyrate aminotransferase (ABAT), and S-adenosylhomocysteine hydrolase (AHCY) (Supplemental Table S2). ABAT, ALDH9A1 and AHCY were all up-regulated in $0.05 \mathrm{mg} / \mathrm{L}$ group, while GLUD1 was down- regulated by 1.58 fold (according to the median value across spots $537,559,603$, and 615) in $5 \mathrm{mg} / \mathrm{L}$ group (Table 1). Fig. 2 shows the relationship between proteins and cell processes related to apoptosis, reactive oxygen species generation, and xenobiotic clearance. Lastly, the process of translation was also significantly affected at the level of the proteome, and proteins such as GAPDH, FASN, and ACO1 were decreased in the network following BT treatments while proteins such as HPRT1, CAT and HSPA8 were increased in this network (Fig. 3). All abbreviations for the protein networks are found in the Figure caption.

\subsection{Validation by $q P C R$}

To validate the alteration of proteins identified after BT exposure, 6 proteins were selected for qPCR analysis (Fig. 4). The transcripts that were assessed included 4-aminobutyrate aminotransferase (abat), probable imidazolonepropionase (amidohydrolase domain containing 1, amdhd1), apolipoprotein A-I (apoa1a), glutamate dehydrogenase 1 (glud1), phosphorylase (pygl), and sulfotransferase family 1, cytosolic sulfotransferase 6 (sult1st6). Transcripts in general showed correspondence with that of the protein abundance (Fig. 4). Here we point out that transcriptional and translation regulation is different, and discrepancies in the regulation of molecular targets by BT can be explained by these two different cell processes. Nevertheless, congruence between gene and protein responses following BT in multiple doses is stronger evidence for disruption of the target. Consistent with the proteomic data, the mRNA levels of abat and amdhd1 presented a marked up-regulation in lower concentrations of BT (Fig. 4). The pattern of apoa1a and sult1st6 mRNA in 0.5 and $5 \mathrm{mg} / \mathrm{L}$ exposure concentrations was in 


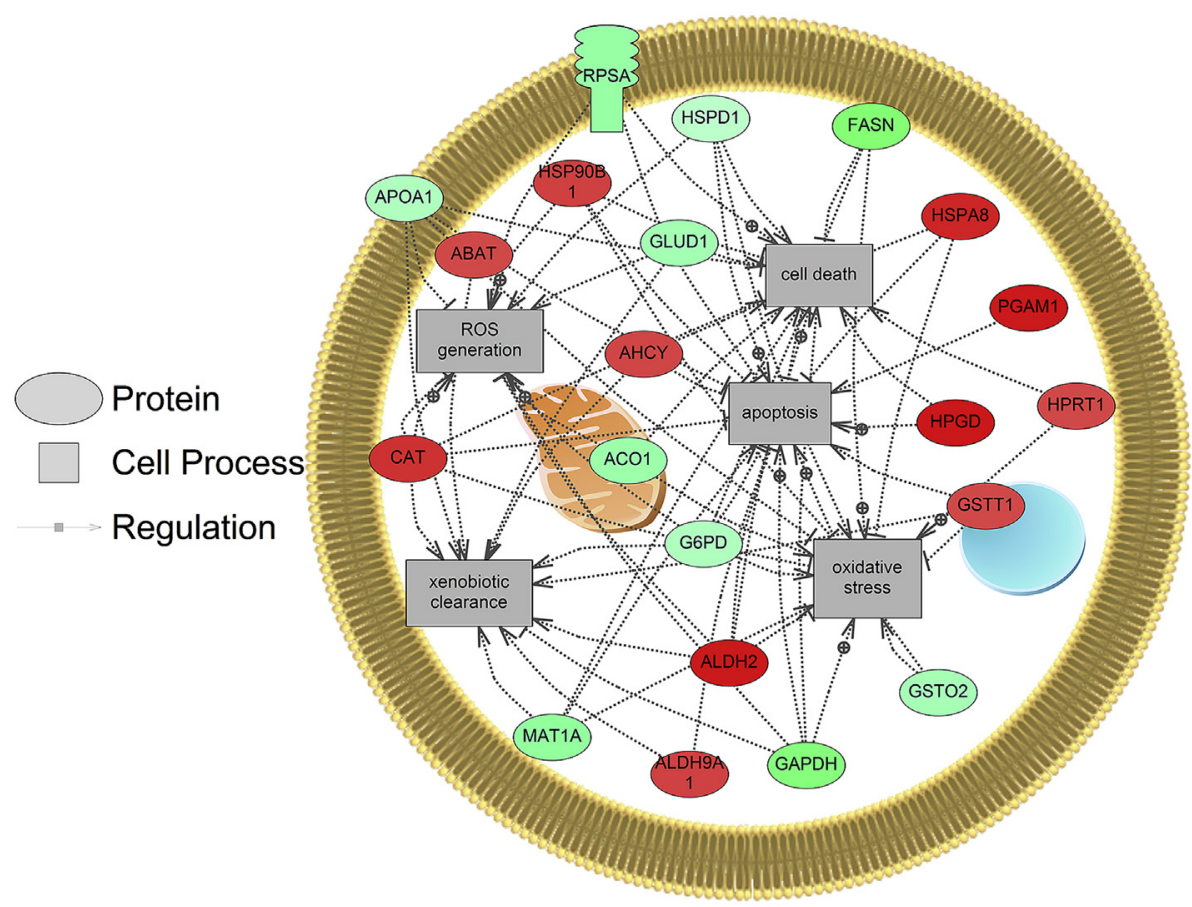

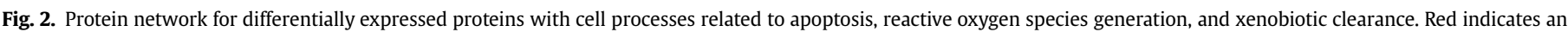

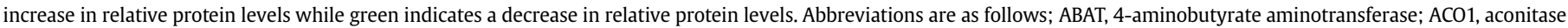

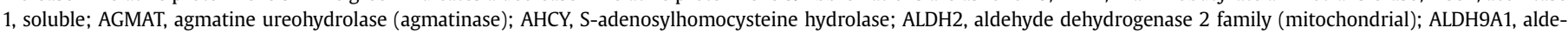

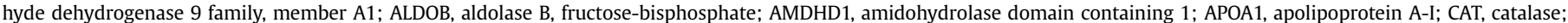

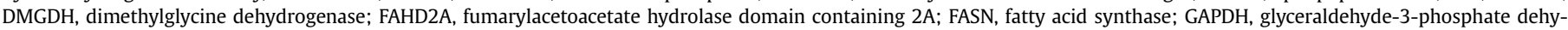

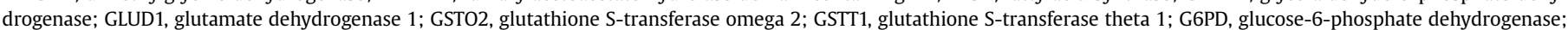

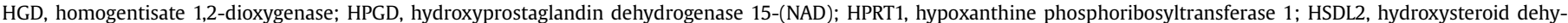

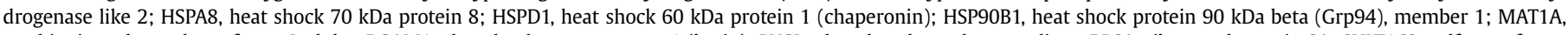

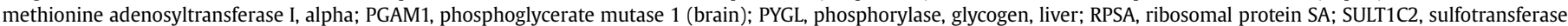
family, cytosolic, 1C, member 2.

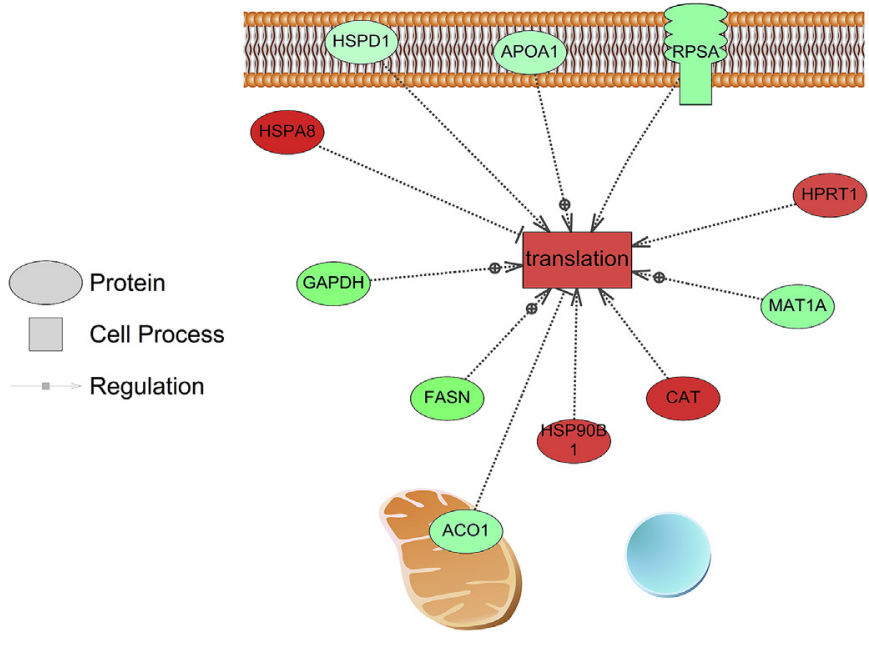

Fig. 3. Protein network for differentially expressed proteins with the process of translation following BT treatments. Red indicates an increase in relative protein levels while green indicates a decrease in relative protein levels. Abbreviations follow that given in the Fig. 2 caption. (For interpretation of the references to colour in this figure legend, the reader is referred to the web version of this article.)

accordance with that of the protein data (Fig. 4). However, in the $0.05 \mathrm{mg} / \mathrm{L}$ group, the apoa1a and sult1st6 mRNA levels were not significantly changed while corresponding protein levels were decreased (Fig. 4). Again, this highlights the complexity underlying gene-protein regulation. In the case where proteins were detected in multiple spots in 2D-DIGE gels, the median value across all spots was used for the protein fold change relative to the control group. Both glud1 and pygl were chosen to validate the protein abundance levels for multiple spot proteins. GLDU1 was down-regulated by 1.58 -fold at $5 \mathrm{mg} / \mathrm{L}$ BT group while PYGL was not significantly altered following all three exposure concentrations of BT. The mRNA levels of glud1 and pygl showed comparable response patterns when compared to protein data generated with DIGE (Fig. 4).

\subsection{Histopathology}

Normal livers in rare minnow typically show compact and tightly arranged hepatocytes with homogeneous cytoplasm, and a large spherical nucleus with one nucleolus (Fig. 5A). Notable histological changes were observed in the livers of the rare minnow following exposure to $0.05,0.5$ and $5 \mathrm{mg} / \mathrm{L}$ BT for $42 \mathrm{~d}$ (Fig. 5B-D) when compared to normal liver histology. Hypertrophy of the hepatocytes, nuclei pyknosis, and increases in cellular vacuolization were observed in all three treatment groups (Fig. 5B-D). Additionally, in the highest BT treatment group, the hypertrophy of the hepatocytes was even more prevalent than the other BT-treated groups (rectangle area in Fig. 5D).

\section{Discussion}

Benzotriazole is an emerging contaminant and is relatively widespread in aquatic environments. Evidence indicates that BT has endocrine disrupting potential (Fent et al., 2014; He et al., 2012; Liang et al., 2014b) and may be neurotoxic (Liang et al., 2016). To 
PYGL

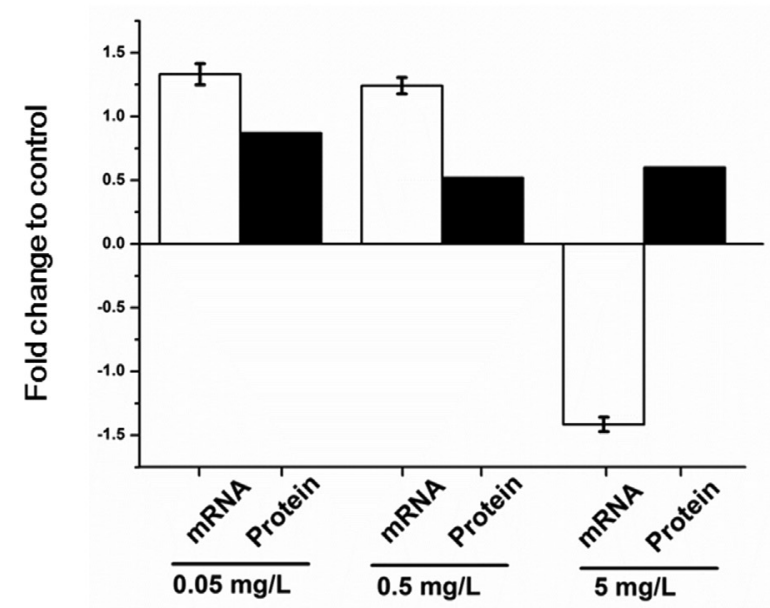

AMDHD1

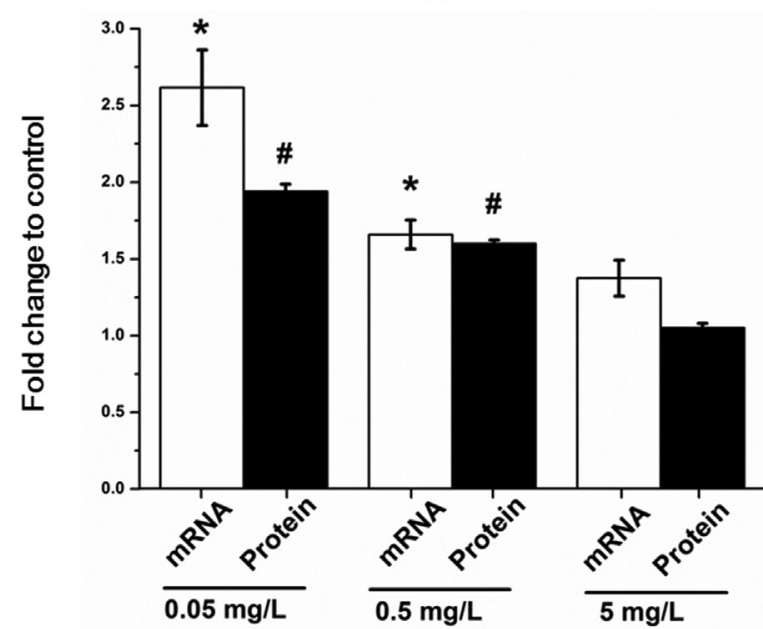

GLUD1

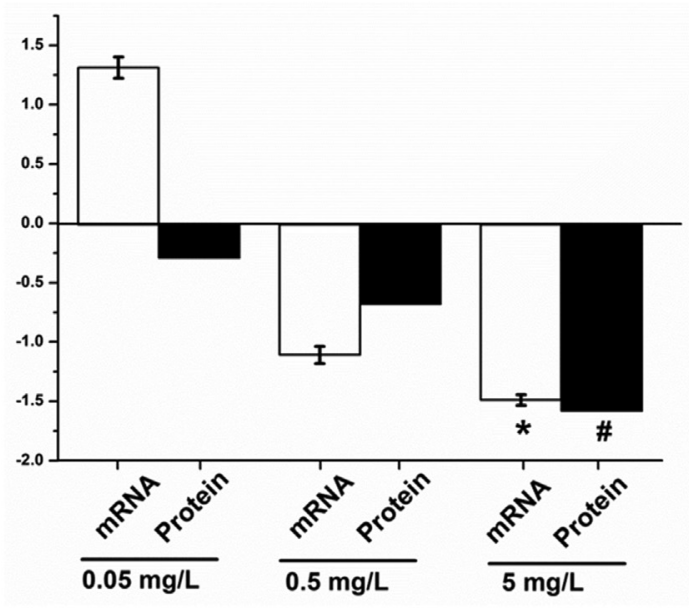

SULTIST6

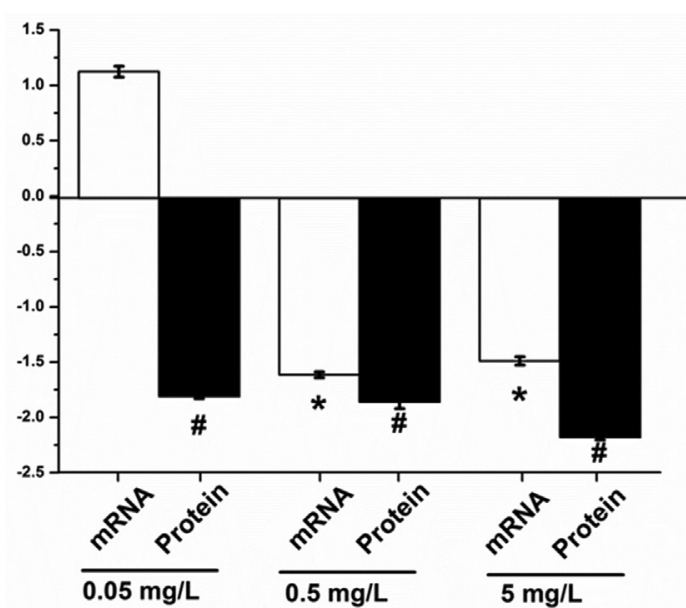

ABAT

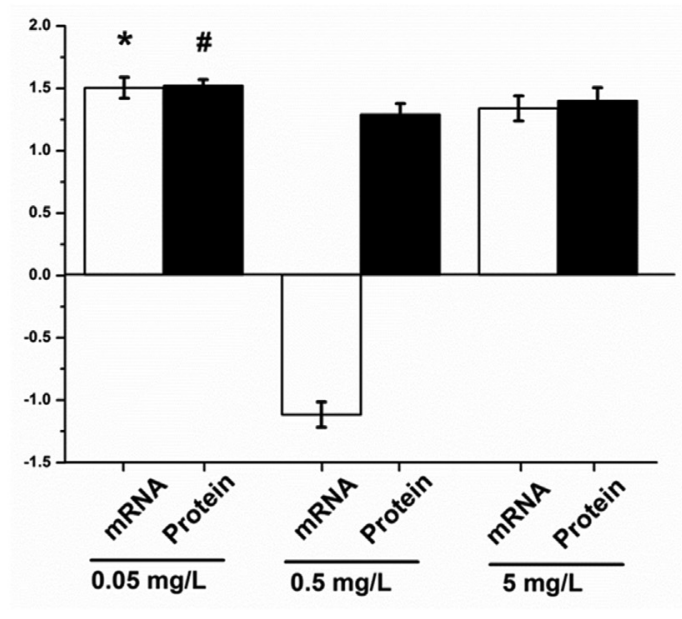

APOA1

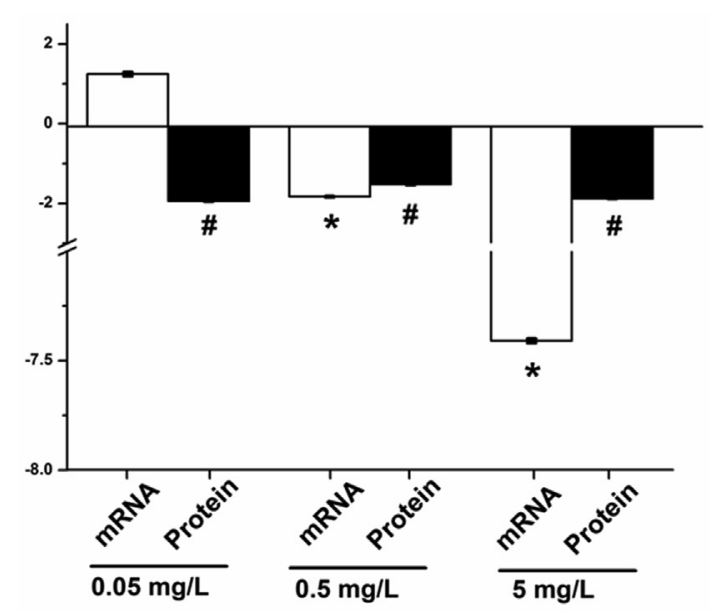

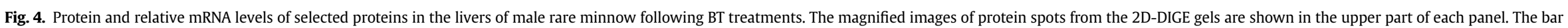

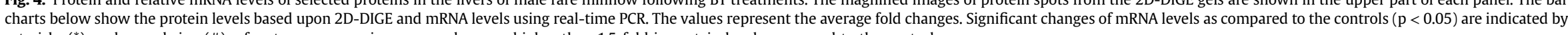
asterisks $\left(^{*}\right)$, and pound sign $(\#)$ refers to an average increase or decrease higher than 1.5-fold in protein levels compared to the controls. 

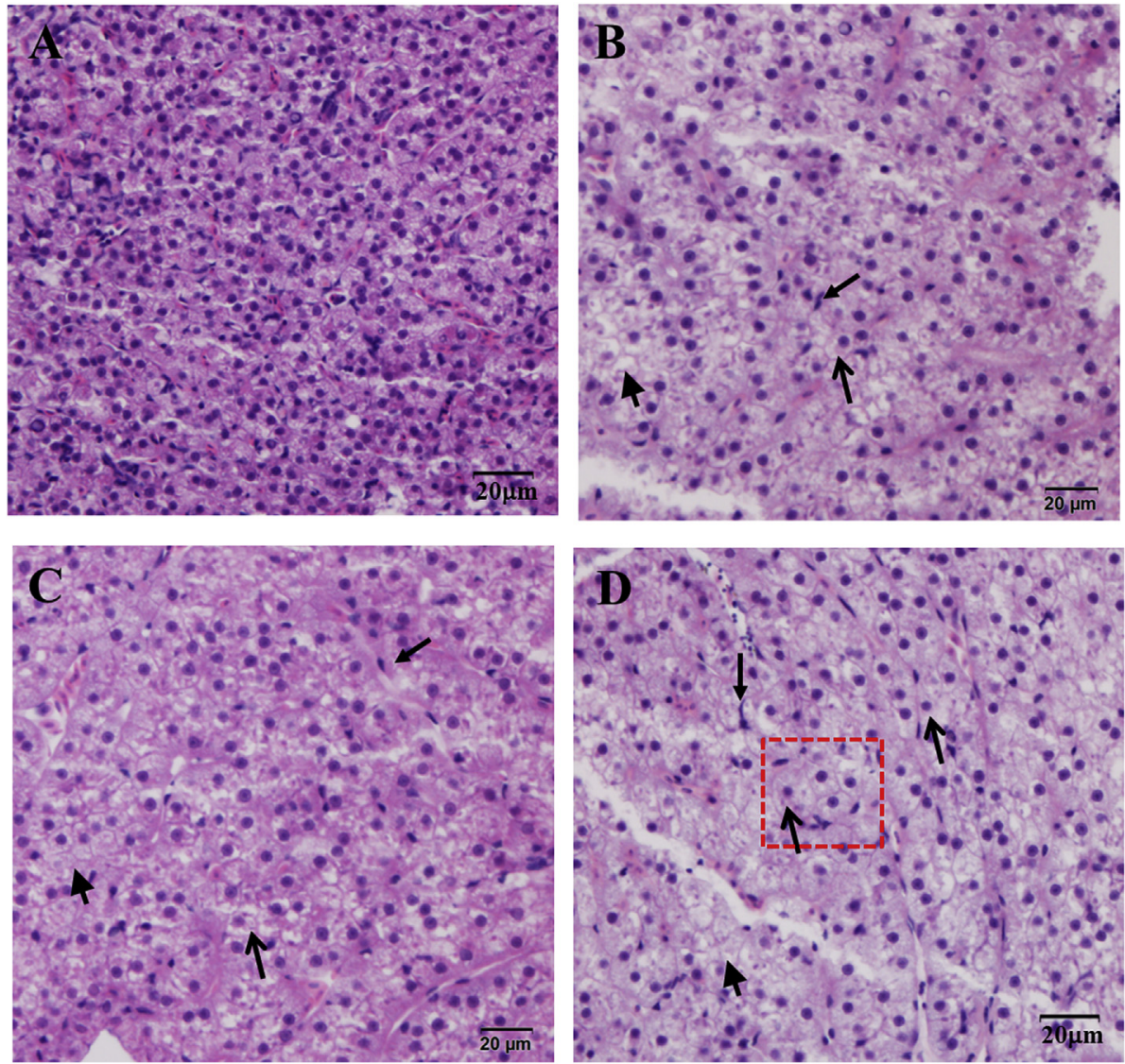

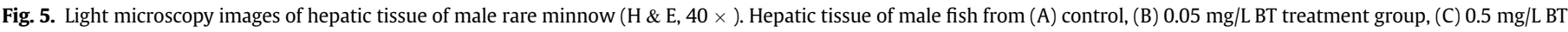

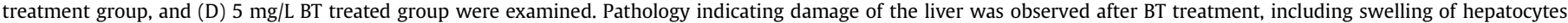
(arrow), vacuolization (arrow ahead) and deformed cell nuclei (solid arrow). Scale bar is $20 \mu \mathrm{M}$.

characterize the liver proteome and to better understand the mechanism of hepatic toxicity of BT, 2D-DIGE coupled MALDI-TOF/ TOF-MS was employed. A total of 32 differentially expressed proteins were identified in one or more of the treatment groups. Of these proteins, 6 were identified in the spot strings as the same protein, which suggests that BT may play a role in protein modification (McCarthy et al., 2003). Although no apparent shifts with MW or PI were observed in exposure gels compared to the control, the protein level of each spot was changed dramatically after BT treatment. We speculate that significant changes in protein modification for some proteins (e.g. phosphorylation) might be induced in response to BT (Lv et al., 2014; Thio et al., 2013), although further studies are needed to verify the extent of phosphorylation.

Pathway analysis revealed that BT-responsive proteins were mainly involved in the process of xenobiotic clearance, oxidative stress response, apoptosis, and translation. In the present study, three primary proteins related to xenobiotic clearance were identified, including SULT1ST6, ABAT, and GLUD1. Our data revealed that SULT1ST6 protein and mRNA were significantly decreased in abundance after BT exposure. SULT1ST6 is a member of sulfotransferases and exhibits sulfating activity toward endogenous compounds of both endocrine and nervous systems in fish (Gao et al., 2014; Liu et al., 2010). Thus, SULT1ST6 is active during detoxification and is also important in metabolizing environmental estrogens (Liu et al., 2008). Previous studies have also shown a significant decrease in sult1st6 mRNA levels in male rare minnow exposed to bisphenol A (Gao et al., 2014) and in zebrafish embryos exposed to chlorpyrifos (Jeon et al., 2016). These results suggest that the hepatic detoxification might be repressed by BT, and further support our previous study reporting on the estrogenic potential of this compound (Liang et al., 2014b).

Additionally, both the transcription and protein levels of ABAT and GLUD1 were significantly increased and decreased in response to 0.05 and $5 \mathrm{mg} / \mathrm{L} \mathrm{BT}$, respectively. As a signaling molecule and neurotransmitter, $\gamma$-Aminobutyric acid (GABA) is produced from glutamate by glutamate decarboxylase and is further metabolized into succinic semialdehyde by ABAT. During this process, GLUD1 converts glutamate to $\alpha$-ketoglutarate, followed by further oxidation in the tricarboxylic acid (TCA) cycle to generate ATP (Bouché et al., 2003; McKenna et al., 1996). According to this metabolic process, we hypothesize that in the current study, the upregulation of ABAT increases GABA, resulting in the downregulation of GLUD1. Aberrant glutamatergic transmission has been associated with neuronal pathology and neurodegenerative diseases (Kim et al., 2011). Environmental chemicals have also been shown to disrupt the normal balance of these enzymes. For example, in the brain of methylmercury-exposed zebrafish, the transcript levels of glud1a and abat were decreased and increased, respectively (Cambier et al., 2012). In addition to the brain, GABA signaling also exists in vertebrate liver, and activation of this GABAergic system can protect the liver against toxic injury (Wang et al., 2017). Li et al. (2016) reported that a repression of this amino acid metabolism pathway is associated with liver impairment in zebrafish exposed to arsenic. In another study, GLUD1 was reported to be downregulated in male rare minnow (Gobiocypris rarus) liver after exposure to pentachlorophenol (Fang et al., 2010). Thus, altered 
protein and transcript levels of ABAT and GLUD1 indicate that BT may disrupt hepatic GABA signaling and induce oxidative stress.

Conversion of glutamate in TCA cycle increases the production of anti-oxidant molecule such as NADPH, thus GABA shunt pathway plays an important role in antioxidant defense (Ramond et al., 2014). Decreased GLUD1 coupled a general induction of heat shock proteins (HSP90B1 and HSPA8) and CAT indicates that there is a general and oxidative stress response in the liver following BT exposure. HSPs are well characterized molecular chaperones that assist in protein folding and are bio-indicators for their sensitivity to environmental stress (Gupta et al., 2010). Catalase is ubiquitous in tissues and acts to reduce hydrogen peroxide and to diminish the effects of reactive oxygen species (ROS) (Nishikawa et al., 2009). An increase in HSPs and catalase activity has been documented in the liver of fathead minnows (Pimephales promelas) responding to $17 \beta-$ trenbolone (an androgen receptor agonist) and flutamide (an androgen receptor antagonist) (Martyniuk et al., 2009). Furthermore, a wide variety of chemicals affect proteins related to ROS production in fish species, including pesticides (Atamaniuk et al., 2013; Martyniuk et al., 2010), and heavy metals (Carlson et al., 2013; Lushchak, 2016). These studies support the hypothesis that BT can induce oxidative stress and adversely affect rare minnow liver at the molecular level.

As a consequence of oxidative stress, cell death and apoptosis may occur and this can result in the hepatotoxicity of BT. Cell death and apoptosis were two of the top pathways identified with subnetwork enrichment analysis and therefore, appear to have a prominent role in BT toxicity. Notably, APOA1, the primary protein constituent of high-density lipoprotein (HDL) and a protein that mediates anti-apoptotic responses in mammals (Rütti et al., 2009), was decreased in each of the exposure concentrations of BT in this study. Inhibition of apoa1 transcripts has also been observed previously in the liver of male goldfish exposed to fluoxetine (FLX) and 17 alpha-ethinylestradiol (EE2) (Silva de Assis et al., 2013), as well as in male zebrafish livers following exposure to waterborne EE2 (Martyniuk et al., 2007). In addition, proteomic analysis in the male rare minnow liver identified proteins that are also associated with the process of translation. These proteins are also involved in apoptosis, suggesting impairment of both protein synthesis and cell death. For example, methionine adenosyltransferase I, alpha (MAT1A) is an essential enzyme that is responsible for the biosynthesis of S-adenosylmethionine. Reduced MAT1A expression in hepatocellular carcinoma contributes to increased apoptosis and enhanced tumorigenesis (Yang et al., 2013). Moreover, the histological damage in the liver of male rare minnow was observed at each concentration in this study and these protein responses may be associated with pathology of the liver in extended exposures. In a previous study, histological damage in the liver of rare minnow exposed to $5 \mathrm{mg} / \mathrm{L}$ BT for 28 days was observed while no significant impacts were examined after 0.05 and $0.5 \mathrm{mg} / \mathrm{L}$ BT treatments (Liang et al., 2014a). These results suggest that the hepatic lesions are caused by BT via disturbing the apoptosis pathway; this damage may be caused at relative low concentrations of BT after longer exposure period.

In conclusion, 2D gel electrophoresis identified proteins affected by BT that are involved in xenobiotic clearance, oxidative stress response, apoptosis, and translation. Furthermore, histological damage in the liver of male rare minnow was observed across all exposure groups following BT exposure. The results presented here provide novel insight into the mechanisms of hepatotoxicity of BT in male rare minnow. We hypothesize that BT induced cellular stress impairs protein synthesis and induces the apoptosis pathway, resulting in ROS production and liver lesions. However, additional experimental validation is required and the biological impacts of long-term BT exposure remain to be examined.

\section{Acknowledgements}

This work was supported by the National Natural Science Foundation of China [grant numbers 21507064, 21677165]; and the Natural Science Foundation of Inner Mongolia Autonomous Region of China [grant number 2015MS0202].

\section{Appendix A. Supplementary data}

Supplementary data related to this article can be found at http:// dx.doi.org/10.1016/j.envpol.2017.06.013.

\section{References}

Asimakopoulos, A.G., Bletsou, A.A., Wu, Q., Thomaidis, N.S., Kannan, K., 2013a. Determination of benzotriazoles and benzothiazoles in human urine by liquid chromatography-tandem mass spectrometry. Anal. Chem. 85, 441-448.

Asimakopoulos, A.G., Wang, L., Thomaidis, N.S., Kannan, K., 2013b. Benzotriazoles and benzothiazoles in human urine from several countries: a perspective on occurrence, biotransformation, and human exposure. Environ. Int. 59, 274-281.

Atamaniuk, T.M., Kubrak, O.I., Storey, K.B., Lushchak, V.I., 2013. Oxidative stress as a mechanism for toxicity of 2,4-dichlorophenoxyacetic acid (2,4-D): studies with goldfish gills. Ecotoxicology 22, 1498-1508.

Bouché, N., Lacombe, B.t, Fromm, H., 2003. GABA signaling: a conserved and ubiquitous mechanism. Trends Cell Biol. 13, 607-610.

Cambier, S., Gonzalez, P., Mesmer-Dudons, N., Brèthes, D., Fujimura, M. Bourdineaud, J.P., 2012. Effects of dietary methylmercury on the zebrafish brain: histological, mitochondrial, and gene transcription analyses. Biometals 25, 165-180.

Carlson, P., Smalley, D.M., Van Beneden, R.J., 2013. Proteomic analysis of arsenicexposed zebrafish (Danio rerio) identifies altered expression in proteins involved in fibrosis and lipid uptake in a gender-specific manner. Toxicol. Sci. 134, 83-91.

Chen, R., Liu, C., Yuan, L., Zha, J., Wang, Z., 2016. 2, 4-Dichloro-6-nitrophenol, a photonitration product of 2,4-dichlorophenol, caused anti-androgenic potency in Chinese rare minnows (Gobiocypris rarus). Environ. Pollut. 216, 591-598.

Fang, Y., Gao, X., Zha, J., Ning, B., Li, X., Gao, Z., Chao, F., 2010. Identification of differential hepatic proteins in rare minnow (Gobiocypris rarus) exposed to pentachlorophenol (PCP) by proteomic analysis. Toxicol. Lett. 199, 69-79.

Fent, K., Chew, G., Li, J., Gomez, E., 2014. Benzotriazole UV-stabilizers and benzotriazole: antiandrogenic activity in vitro and activation of aryl hydrocarbon receptor pathway in zebrafish eleuthero-embryos. Sci. Total Environ. 482, $125-136$.

Gao, J., Zhang, Y., Yang, Y., Yuan, C., Qin, F., Liu, S., Zheng, Y., Wang, Z., 2014. Molecular characterization of PXR and two sulfotransferases and hepatic transcripts of PXR, two sulfotransferases and CYP3A responsive to bisphenol A in rare minnow Gobiocypris rarus. Mol. Biol. Rep. 41, 7153-7165.

Giger, W., Schaffner, C., Kohler, H.P.E., 2006. Benzotriazole and tolyltriazole as aquatic contaminants. 1. Input and occurrence in rivers and lakes. Environ. Sci. Technol. 40, 7186-7192.

Gupta, S.C., Sharma, A., Mishra, M., Mishra, R.K., Chowdhuri, D.K., 2010. Heat shock proteins in toxicology: how close and how far? Life Sci. 86, 377-384.

He, T., Liang, B., Liu, W., Shin, P.K.S., Wu, R.S.S., 2012. Estrogenic potential of benzotriazole on marine medaka (Oryzias melastigma). Ecotoxicol. Environ. Saf. 80, 327-332.

Herrero, P., Borrull, F., Pocurull, E., Marcé, R.M., 2013. Efficient tandem solid-phase extraction and liquid chromatography-triple quadrupole mass spectrometry method to determine polar benzotriazole, benzothiazole and benzenesulfonamide contaminants in environmental water samples. J. Chromatogr. A 1309, $22-32$.

Herzog, B., Lemmer, H., Helmreich, B., Horn, H., Müller, E., 2014. Monitoring benzotriazoles: a 1 year study on concentrations and removal efficiencies in three different wastewater treatment plants. Water Sci. Technol. 69, 710-717.

Janna, H., Scrimshaw, M.D., Williams, R.J., Churchley, J., Sumpter, J.P., 2011. From dishwasher to tap? xenobiotic substances benzotriazole and tolyltriazole in the environment. Environ. Sci. Technol. 45, 3858-3864.

Jeon, H.J., Lee, Y.H., Kim, M.J., Choi, S.D., Park, B.J., Lee, S.E., 2016. Integrated biomarkers induced by chlorpyrifos in two different life stages of zebrafish (Danio rerio) for environmental risk assessment. Environ. Toxicol. Pharmacol. 43, $166-174$.

Kim, K., Lee, S.G., Kegelman, T.P., Su, Z.Z., Das, S.K., Dash, R., Dasgupta, S., Barral, P.M. Hedvat, M., Diaz, P., 2011. Role of excitatory amino acid transporter-2 (EAAT2) and glutamate in neurodegeneration: opportunities for developing novel therapeutics. J. Cell. Physiol. 226, 2484-2493.

Kiss, A., Fries, E., 2009. Occurrence of benzotriazoles in the rivers Main, Hengstbach, and Hegbach (Germany). Environ. Sci. Pollut. Res. 16, 702-710.

Langlois, V.S., Martyniuk, C.J., 2013. Genome wide analysis of Silurana (Xenopus) tropicalis development reveals dynamic expression using network enrichment analysis. Mech. Dev. 130, 304-322.

Li, C., Li, P., Tan, Y.M., Lam, S.H., Chan, E.C.Y., Gong, Z., 2016. Metabolomic 
characterizations of liver injury caused by acute arsenic toxicity in zebrafish. PLoS One 11, e0151225.

Liang, X., Martyniuk, C.J., Cheng, G., Zha, J., Wang, Z., 2014a. Pyruvate carboxylase as a sensitive protein biomarker for exogenous steroid chemicals. Environ. Pollut. 189, 184-193.

Liang, X., Martyniuk, C.J., Zha, J., Wang, Z., 2016. Brain quantitative proteomic responses reveal new insight of benzotriazole neurotoxicity in female Chinese rare minnow (Gobiocypris rarus). Aquat. Toxicol. 181, 67-75.

Liang, X., Wang, M., Chen, X., Zha, J., Chen, H., Zhu, L., Wang, Z., 2014b. Endocrine disrupting effects of benzotriazole in rare minnow (Gobiocypris rarus) in a sexdependent manner. Chemosphere 112, 154-162.

Liang, X., Zha, J., 2016. Toxicogenomic applications of Chinese rare minnow (Gobiocypris rarus) in aquatic toxicology. Comp. Biochem. Physiol. D. Genomics Proteomics 19, 174-180.

Liu, T.A., Bhuiyan, S., Liu, M.Y., Sugahara, T., Sakakibara, Y., Suiko, M., Yasuda, S. Kakuta, Y., Kimura, M., Williams F, E., Liu, M.C., 2010. Zebrafish as a model for the study of the phase II cytosolic sulfotransferases. Curr. Drug Metab. 11, $538-546$.

Liu, T.A., Bhuiyan, S., Snow, R., Yasuda, S., Yasuda, T., Yang, Y.S., Williams, F.E., Liu, M.Y., Suiko, M., Carter, G., Liu, M.-C., 2008. Identification and characterization of two novel cytosolic sulfotransferases, SULT1 ST7 and SULT1 ST8, from zebrafish. Aquat. Toxicol. 89, 94-102.

Liu, Y.S., Ying, G.G., Shareef, A., Kookana, R.S., 2011. Simultaneous determination of benzotriazoles and ultraviolet filters in ground water, effluent and biosolid samples using gas chromatography-tandem mass spectrometry. J. Chromatogra. A 1218, 5328-5335.

Liu, Y.S., Ying, G.G., Shareef, A., Kookana, R.S., 2012. Occurrence and removal of benzotriazoles and ultraviolet filters in a municipal wastewater treatment plant. Environ. Pollut. 165, 225-232.

Loos, R., Gawlik, B.M., Locoro, G., Rimaviciute, E., Contini, S., Bidoglio, G., 2009. EUwide survey of polar organic persistent pollutants in European river waters. Environ. Pollut. 157, 561-568.

Lushchak, V.I., 2016. Contaminant-induced oxidative stress in fish: a mechanistic approach. Fish. Physiol. Biochem. 42, 711-747.

Lv, D.W., Subburaj, S., Cao, M., Yan, X., Li, X., Appels, R., Sun, D.F., Ma, W., Yan, Y.M. 2014. Proteome and phosphoproteome characterization reveals new response and defense mechanisms of brachypodium distachyon Leaves under salt stress. Mol. Cell. Proteomics 13, 632-652.

Martyniuk, C.J., Alvarez, S., McClung, S., Villeneuve, D.L., Ankley, G.T., Denslow, N.D. 2009. Quantitative proteomic profiles of androgen receptor signaling in the liver of fathead minnows (Pimephales promelas). J. Proteome Res. 8, 2186-2200.

Martyniuk, C.J., Gerrie, E.R., Popesku, J.T., Ekker, M., Trudeau, V.L., 2007. Microarray analysis in the zebrafish (Danio rerio) liver and telencephalon after exposure to low concentration of 17alpha-ethinylestradiol. Aquat. Toxicol. 84, 38-49.

Martyniuk, C.J., Kroll, K.J., Doperalski, N.J., Barber, D.S., Denslow, N.D., 2010 Genomic and proteomic responses to environmentally relevant exposures to dieldrin: indicators of neurodegeneration? Toxicol. Sci. 117, 190-199.

McCarthy, J., Hopwood, F., Oxley, D., Laver, M., Castagna, A., Righetti, P.G. Williams, K., Herbert, B., 2003. Carbamylation of proteins in 2-D electrophoresis- myth or reality? J. Proteome Res. 2, 239-242.

McKenna, M.C., Sonnewald, U., Huang, X., Stevenson, J., Zielke, H.R., 1996
Exogenous glutamate concentration regulates the metabolic fate of glutamate in astrocytes. J. Neurochem. 66, 386-393.

Nishikawa, M., Hashida, M., Takakura, Y., 2009. Catalase delivery for inhibiting ROSmediated tissue injury and tumor metastasis. Adv. Drug Deliv. Rev. 61, 319-326.

Pillard, D.A., Cornell, J.S., DuFresne, D.L., Hernandez, M.T., 2001. Toxicity of benzotriazole and benzotriazole derivatives to three aquatic species. Water Res. 35, $557-560$.

Ramond, E., Gesbert, G., Rigard, M., Dairou, J., Dupuis, M., Dubail, I., Meibom, K., Henry, T., Barel, M., Charbit, A., 2014. Glutamate utilization couples oxidative stress defense and the tricarboxylic acid cycle in Francisella phagosomal escape. PLoS Pathog. 10, e1003893.

Rütti, S., Ehses, J.A., Sibler, R.A., Prazak, R., Rohrer, L., Georgopoulos, S., Meier, D.T., Niclauss, N., Berney, T., Donath, M.Y., von Eckardstein, A., 2009. Low- and highdensity lipoproteins modulate function, apoptosis, and proliferation of primary human and murine pancreatic $\beta$-cells. Endocrinology 150, 4521-4530.

Richardson, S.D., 2009. Water analysis: emerging contaminants and current issues. Anal. Chem. 81, 4645-4677.

Seeland, A., Oetken, M., Kiss, A., Fries, E., Oehlmann, J., 2012. Acute and chronic toxicity of benzotriazoles to aquatic organisms. Environ. Sci. Pollut. Res. 19, 1781-1790.

Silva de Assis, H.C., Simmons, D.B.D., Zamora, J.M., Lado, W.E., Al-Ansari, A.M., Sherry, J.P., Blais, J.M., Metcalfe, C.D., Trudeau, V.L., 2013. Estrogen-like effects in male goldfish co-exposed to fluoxetine and 17 alpha-ethinylestradiol. Environ. Sci. Technol. 47, 5372-5382.

Thio, C.L.P., Yusof, R., Abdul-Rahman, P.S.A., Karsani, S.A., 2013. Differential proteome analysis of chikungunya virus infection on host cells. PLoS One 8, e61444

Voutsa, D., Hartmann, P., Schaffner, C., Giger, W., 2006. Benzotriazoles, alkylphenols and bisphenol A in municipal wastewaters and in the Glatt River, Switzerland. Environ. Sci. Pollut. Res. 13, 333-341.

Wang, L., Asimakopoulos, A.G., Kannan, K., 2015. Accumulation of 19 environmental phenolic and xenobiotic heterocyclic aromatic compounds in human adipose tissue. Environ. Int. 78, 45-50.

Wang, L., Asimakopoulos, A.G., Moon, H.B., Nakata, H., Kannan, K., 2013. Benzotriazole, benzothiazole, and benzophenone compounds in indoor dust from the United States and East Asian countries. Environ. Sci. Technol. 47, 4752-4759.

Wang, S., Xiang, Y.Y., Zhu, J., Yi, F., Li, J., Liu, C., Lu, W.Y., 2017. Protective roles of hepatic GABA signaling in acute liver injury of rats. Am. J. Physiol. Gastrointest. Liver Physiol. 312, G208-G218.

Weiss, S., Reemtsma, T., 2005. Determination of benzotriazole corrosion inhibitors from aqueous environmental samples by liquid chromatography-electrospray ionization-tandem mass spectrometry. Anal. Chem. 77, 7415-7420.

Wolschke, H., Xie, Z., Möller, A., Sturm, R., Ebinghaus, R., 2011. Occurrence, distribution and fluxes of benzotriazoles along the German large river basins into the North Sea. Water Res. 45, 6259-6266.

Yang, H., Cho, M.E., Li, T.W.H., Peng, H., Ko, K.S., Mato, J.M., Lu, S.C., 2013. MicroRNAs regulate methionine adenosyltransferase $1 \mathrm{~A}$ expression in hepatocellular carcinoma. J. Clin. Invest 123, 285-298.

Zha, J., Sun, L., Zhou, Y., Spear, P.A., Ma, M., Wang, Z., 2008. Assessment of $17 \alpha_{-}$ ethinylestradiol effects and underlying mechanisms in a continuous, multigeneration exposure of the Chinese rare minnow (Gobiocypris rarus). Toxicol. Appl. Pharmacol. 226, 298-308. 